\title{
Visual Characteristics of National Unity in Malaysian Comics
}

Mohamad Quzami An-Nuur bin Ahmad Radzi, Nur Hisham Ibrahim, Muhamad Abdul Aziz bin Ab Gani, Nur Liana Kamal Bahari

To Link this Article: http://dx.doi.org/10.6007/IJARBSS/v12-i1/12063

DOI:10.6007/IJARBSS/v12-i1/12063

Received: 04 November 2021, Revised: 06 December 2021, Accepted: 28 December 2021

Published Online: 23 January 2022

In-Text Citation: (Radzi et al., 2022)

To Cite this Article: Radzi, M. Q. A.-N. bin A., Ibrahim, N. H., Gani, M. A. A. bin A., \& Bahari, N. L. K. (2022). Visual Characteristics of National Unity in Malaysian Comics. International Journal of Academic Research in Business and Social Sciences, 12(1), 1787-1792.

\section{Copyright: @ 2022 The Author(s)}

Published by Human Resource Management Academic Research Society (www.hrmars.com)

This article is published under the Creative Commons Attribution (CC BY 4.0) license. Anyone may reproduce, distribute, translate and create derivative works of this article (for both commercial and non0-commercial purposes), subject to full attribution to the original publication and authors. The full terms of this license may be seen at: http://creativecommons.org/licences/by/4.0/legalcode

Vol. 12, No. 1, 2022, Pg. 1787- 1792

Full Terms \& Conditions of access and use can be found at http://hrmars.com/index.php/pages/detail/publication-ethics 


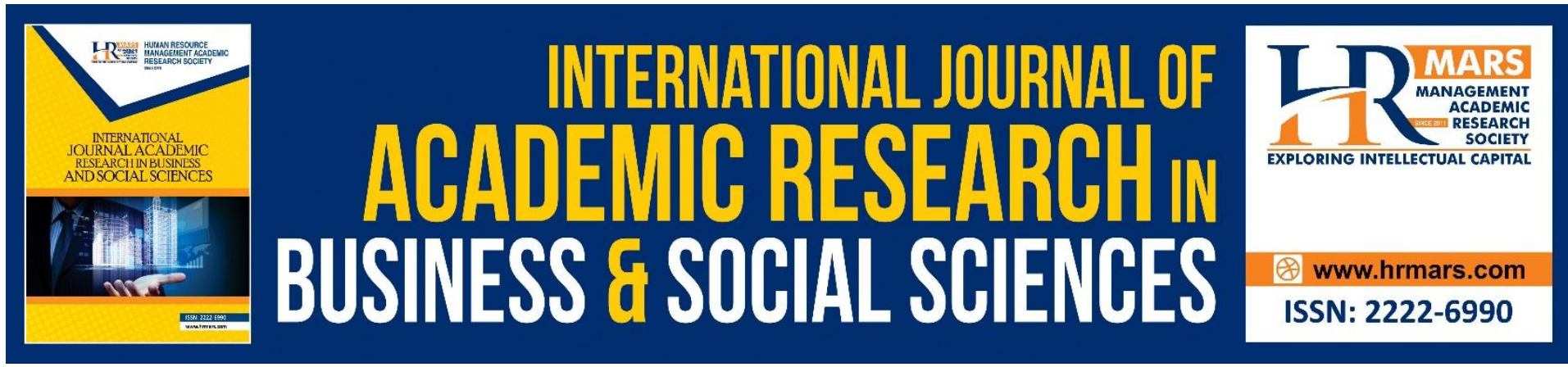

\title{
Visual Characteristics of National Unity in Malaysian Comics
}

\author{
Mohamad Quzami An-Nuur bin Ahmad Radzi ${ }^{1}$, Nur Hisham \\ Ibrahim², Muhamad Abdul Aziz bin Ab Gani³ ${ }^{3}$ Nur Liana Kamal \\ Bahari ${ }^{4}$ \\ ${ }^{23}$ Faculty of Art and Design, Universiti Teknologi MARA, Perak Branch, Seri Iskandar, Perak \\ ${ }^{14}$ Faculty of Art and Design, Universiti Teknologi MARA, Shah Alam, Selangor, Malaysia \\ Email: quzami@uitm.edu.my,nurhi540@uitm.edu.my, aziz354@uitm.edu.my, \\ 2020864514@uitm.edu.my
}

\begin{abstract}
This preliminary paper is a part of an ongoing research to study the relationship between the theme on Malaysian unity presented in Malaysian comics. This research has been conducted by collecting existing related literatures and local Malaysian origin comic visuals which has therefore fulfilled the objective of this paper. Visual analysis method to identify visual characteristics reflecting theme on national unity in Malaysian comics has been applied in this study. Therefore, this research may serve a better understanding to the public, audience, artist, and future researcher on the relationship between Malaysian origin comics and the concept of Malaysian national unity.
\end{abstract}

Keywords: Comic, Unity, National Unity, Visual Analysis

\section{Introduction}

Comics can be referred to as a medium of expression of humour combined with its storyline (Dewan Bahasa dan Pustaka, 2007). It is considered as an expression of art that is close to the audience and is one of easiest forms of visual communication which can be found as regular comic, graphic novel, strips, and panel style comic (Darnhofer, 2018). Comics in newspapers are typically in the form of strip style which contains a short story that connects to each series that are continuous, sequential, and meaningful (Ryall \& Tipton, 2009). Comic presence moreover comes in many other forms, the contents, and characteristics.

According to Ryall and Tipton (2009), the first comic was found and recorded in the year of 1900. The history of comics underwent a revolution that caters to different usages, characters, and themes for overall comic design during this time period. The first comic was publicised in the late $18^{\text {th }}$ to $19^{\text {th }}$ era, known as the Victorian Age. The Victorian Age was then followed by the Golden Age and gained much popularity after Cold and World War 2. The next period of comics was the Atom Age in which the theme of romance, horror, and science fiction in comic storylines first emerged. The Bronze Age of comic books, following the Atom Age dealt with darker storylines that focused on political issues and drug abuse. The theme around 
comic has then been reevaluated until today where comic editorial ought to deliver positive theme within the comics.

To gauge a better understanding on the comic process itself, there are board of editorial and supporting theme where each of the team members are assigned with a job description and requirements that will meet the final output of the comic. The writer, also known as the master mind of the whole comic storyline, creates a direction in the whole comic design process (Khamdamovna, 2020) and produces the first draft of the comic. The next step involves the Penciler who contributes to the creation of the main visual of the comic designs. The Penciler is then assisted by the Inker in giving the comic a realistic look with added special elements (Bocart et al., 2019). Colorist will then take over the next stage by adding colours and effects to the comic (Ryall \& Tipton, 2009; Yockey, 2017) followed by the letterer who contributes as the typeface placement artist (Zanettin, 2018). The team members involved in the comic design process are monitored closely by the editor (Friedlander, 2018).

The overall comic design process must be strictly evaluated, monitored, and adhered to ensure the highest quality of the whole concept of the comic. Every single person involved in the comic design process must understand that comics are considered as a medium of communication. As such, a proper guideline is vital in producing quality comics moving forward. In the context of comic themes, the concept of unity or national unity specifically in Malaysia should be considered as a local theme and be fully understood before proceeding to the actual comic design process itself.

\section{Unity in Malaysia}

The concept of unity is a part of Malaysia's national agenda (Ruzki, 2021). This is due to the fact that Malaysia is known as a multiethnic country. In order to cultivate unity and harmony, it is pivotal for every person in Malaysia to tolerate and accept one another, regardless of race and colour and celebrate diversity. However, the concept of unity must be fully understood amongst the multicultural society in Malaysia. To achieve this, every single person in the community plays an essential role in the attempt to maintain and gain unity spirit among Malaysians.

The concept was deeply rooted in Malaysia since the $13^{\text {th }}$ of May 1969 tragedy and has since then been reinvent with improved unity planning (Kementerian Perpaduan Negara, 2021). It was considered as a national agenda which aims to promote unity amongst the community to achieve racial harmony and peace. A variety of communication tool must be implemented in support of the national agenda to nurture the spirit amongst Malaysians.

The effort to cultivate unity among Malaysians had practically started during early childhood. This practice became part and parcel of Malaysia's culture and heritage to foster a dynamic and loving country that celebrates diversity and equality. Some of the examples of these practices include singing the national song, which is Negaraku, greeting each other, hand kissing as a greeting gesture to indicate respect and courtesy towards the elderly, and reciting the national principles or better known as the Rukun Negara at every official assembly in school (Mamat et al., 2019). Despite all these efforts practiced in Malaysia to promote unity, it is important to introduce other effective communication tools in line with community maturity and current situation.

One of the ways to promote unity amongst Malaysians is through visual arts in the form of mural projects. Murals are considered as huge paintings produced by artists with a specific theme and message. The 32 murals at Gertak Sanggul Primary school, Penang was a project of visual art that helped convey message of unity towards the community (Zulkifli, 2021). The 
theme on patriotism and unity that was presented through visual art projects reflects the overall murals that had been created. This proves that visual art is capable of becoming an effective communication tool and a medium to promote unity among the Malaysian community.

Further, the Malaysian government plays a role in supporting this national agenda. Former Malaysia Prime Minister Tan Sri Muhyiddin Yassin had in February 2021 launched an initiative to promote unity (Kementerian Perpaduan Negara, 2021), supported by the Malaysian government based off the National Principles. This shows the importance of national unity in a multiethnic country like Malaysia where a national agenda is capable of reaching high expectations when supported with proper planning on the part of the government.

\section{Problem Statements}

The current national unity campaigns held in Malaysia is not seemingly impactful to the community. The lack of results may occur due to communication barrier faced during campaigns. As we all are aware by now, effective communication is vital to produce victorious campaign that serves its purpose. Therefore, comics can be considered as a communication tool in the form of visual art as comics interact with audience's emotions (Lee et al., 2019).

Aside from that, local Malaysian comics lack the element of unity that can be helpful in demonstrating values of equality, acceptance, and understanding among audience. Artists need to manipulate comic into becoming an effective communication tool that can cultivate and nurture Malaysia's national agenda. According to Idris (2019), political, current issues, and propaganda added into comics have been reported as topics of interest amongst the audience which may negatively impact national unity.

\section{Research Objectives}

- To identify the element of national unity in Malaysian comics

- To analyse the element of national unity in Malaysian comics

\section{Methodology}

This paper uses qualitative method namely visual analysis as its main method of data collection, which assisted researchers to fulfill the objectives of this paper. The visual analysis is considered as a method that analyses visual sources based on art history (D'Alleva, 2016). There are three phases presented in this paper that been summarised in Table 1 below:

Table 1: Research phases

\begin{tabular}{|l|l|}
\hline Phase & Activity \\
\hline One & Collecting literature related to unity program and comic. \\
\hline Two & Analyzing comic presenting unity \\
\hline Three & Identify unity characteristics in local comic \\
\hline
\end{tabular}

In detail, variety of past literatures and Malaysian Comics have been collected in Phase One. Researchers have further identified possible past literatures on Malaysian comics during this Phase. In the Second Phase, researchers ran visual analysis by way of analysing various Malaysian comics that are related and/or present elements of national unity. The Third Phase which followed thereafter focused on identifying and sorting out the characteristics of Malaysians comics in relation to the element of national unity in Malaysia. 


\section{National Unity in Malaysian Comics}

Previous study mentioned that Malaysian comics related to the element of unity emerged from pre-independence around the year 1950. The agenda on cultivating patriotism among Malaysians during the time period was the result of comics being specifically focused on the storyline on unity. Artists at that time dealt with current issues that drove the community towards independence, which was further brought to even after post-independence. However, Malaysian comics that helped foster unity, patriotism, and harmony in the community incorporated visual arts. The metaphor behind comic visualisation even until today upholds the national agenda to foster national unity among Malaysians. Below is a summary of visual characteristics of the element of national unity presented in Malaysia comics:

Table 2: Summary of national unity visual characteristics

\begin{tabular}{|l|l|}
\hline Artist or comic title & National unity visual characteristics \\
\hline $\begin{array}{l}\text { Mat Som, Town Boy, } \\
\text { Keluarga Si Mamat and } \\
\text { Kampung Boy }\end{array}$ & $\begin{array}{l}\text { Multiethnicity, local culture, heritage, harmony, friendship, and } \\
\text { local village environment }\end{array}$ \\
\hline $\begin{array}{l}\text { Scene of life newspaper } \\
\text { comics }\end{array}$ & Multiracial culture \\
\hline Rahim & Unity and harmony \\
\hline $\begin{array}{l}\text { Good morning Malaysia } \\
\text { and Can or Not }\end{array}$ & Showcasing Malaysia's uniqueness by way of humor \\
\hline
\end{tabular}

\section{Conclusion}

As a conclusion, the concept of national unity presented in comics can be beneficial for various reasons. As such, comic artists are strongly encouraged to continuously promote and foster national unity by adding such elements into their comics and avoid negative themes around hate, agony, and spreading misleading information. Artists must however have a full understanding of the concept of national unity before incorporating the same into their comics.

Other than that, any possible variables related to Malaysian comics, or any comic origin also may be studied in future. Other characteristics that are related to the comic also can be an interesting topic to be studied in future too. Next, future researchers may adopt research methodology that has been practiced in this paper too, if necessary, and may adjust the research phases that related to them. Any other future visuals study also can refer to this research paper as example of visual analysis research method.

\section{References}

Bocart, F., Hafner, C., Kasperskaya, Y., \& Sagarra, M. (2019). Investing in superheroes? Comic art as a new alternative investment. Center for Operations Research and Econometrics (CORE). https://alfresco.uclouvain.be/alfresco/service/guest/streamDownload/workspace/Spa cesStore/cebbd0d5-3ec1-4e70-8383-

8d6650df654f/coredp2019_16web.pdf?guest=true

D’Alleva, A. (2016). How to write art history. Laurence King. 
Darnhofer, I. (2018). Using comic-style posters for engaging participants and for promoting researcher reflexivity. International Journal of Qualitative Methods, 17(1), 160940691880471. https://doi.org/10.1177/1609406918804716

Dewan Bahasa dan Pustaka. (2007). Kamus dewan (4th ed.). Dewan Bahasa dan Pustaka.

Friedlander, K. (2018). The editor, the author function, and the social function: A methodological survey. Journal of Graphic Novels and Comics, 9(2), 157-172. https://doi.org/10.1080/21504857.2017.1355819

Idris, R. (2019). GERAKAN gesa polis ambil tindakan terhadap pelukis komik. Berita Harian. https://www.bharian.com.my/berita/kes/2019/10/620765/gerakan-gesa-polis-ambiltindakan-terhadap-pelukis-komik

Kementerian Perpaduan Negara. (2021). Dasar perpaduan negara - Perpaduan dalam kepelbagaian. Kementerian Perpaduan Negara.

https://www.perpaduan.gov.my/images/document/penerbitan/Dasar_Perpaduan_Ne gara-1.pdf

Khamdamovna, M. U. (2020). Similarities and differences between types of comic. International Journal on Integrated Education, 3(9), 105-107. https://doi.org/10.31149/ijie.v3i9.596

Lee, T.-I., Sheu, S.-J., Chang, H.-C., Hung, Y.-T., Tseng, L.-M., Chou, S.-S., Liang, T.-H., Liu, H.-J., Lu, H.-L., Chen, M.-C., Liu, Y.-C., Tsai, C.-S., \& Sun, J.-C. (2019). Developing a web-based comic for newly diagnosed women with breast cancer: An action research approach. Journal of Medical Internet Research, 21(2), e10716. https://doi.org/10.2196/10716

Mamat, R., Abd Rahim, N., Affendi, N. M. N. R., \& Abdul Rashid, R. (2019). Perkembangan komik dan animasi: Satu kajian perbandingan antara Melayu dan Jepun. Malaysian Journal of Communication, 35(2), 260-276.

http://ejournal.ukm.my/mjc/issue/view/1200

Ruzki, R. M. (2021). 3 objektif utama Dasar Perpaduan Negara - PM. Berita Harian. https://www.bharian.com.my/berita/nasional/2021/02/786274/3-objektif-utamadasar-perpaduan-negara-pm

Ryall, C., \& Tipton, S. (2009). Comic books 101: The history, methods and madness. IMPACT.

Yockey, M. (2017). Make ours marvel media convergence and a comics universe. University of Texas Press.

Zanettin, F. (2018). Translating comics and graphic novels. In S.-A. Harding \& O. C. Cortés (Eds.), The Routledge handbook of translation and culture (1st ed.). Routledge. https://doi.org/10.4324/9781315670898

Zulkifli, Z. (2021). Sambut Hari Malaysia dengan 32 mural. Berita Harian. https://www.bharian.com.my/berita/pendidikan/2021/09/863698/sambut-harimalaysia-dengan-32-mural 